\title{
UJI AKTIVITAS ANTIOKSIDAN GULA AREN
}

\author{
Elly Juliana Suoth ${ }^{*}$, Rina Herowati ${ }^{1}$, Gunawan Pamudji ${ }^{1}$ \\ ${ }^{1}$ Fakultas Farmasi, Universitas Setia Budi \\ J1. Letjen Sutoyo-Mojosongo Surakarta
}

\begin{abstract}
ABSTRAK
Gula aren dengan dosis $200 \mathrm{mg} / \mathrm{kg}$ BB dan $400 \mathrm{mg} / \mathrm{kg}$ BB diberikan pada tikus putih yang kemudian diinduksi $\mathrm{CCl}_{4}$ $1,5 \mathrm{ml} / \mathrm{kg}$ BB. Penelitian ini bertujuan untuk melihat kadar enzim antioksidan yaitu SOD dan GPx setelah diinduksi $\mathrm{CCl}_{4}$ serta kerusakan yang ditimbulkan oleh $\mathrm{CCl}_{4}$ lewat pengukuran kadar MDA. Hasil penelitian menunjukkan bahwa kadar SOD dan GPX pada tikus kontrol negatif berbeda dengan kadar SOD dan GPx pada tikus yang diberikan gula aren. Kadar enzim antioksidan pada tikus yang diberikan gula aren hampir sama dengan tikus normal (kelompok yang tidak diinduksi $\mathrm{CCl}_{4}$ ). Hal tersebut berhubungan dengan kadar MDA dimana pada tikus kelompok kontrol negatif menunjukkan kadar MDA yang tinggi sedangkan pada tikus normal dan tikus yang diberikan gula aren menunjukkan kadar MDA rendah yang artinya bahwa enzim antioksidan pada tikus normal dan tikus yang diberikan gula aren mengadakan peredaman terhadap reaksi oksidasi yang disebabkan oleh $\mathrm{CCl}_{4}$ sehingga peroksidasi lipid yang terjadi sangat kecil
\end{abstract}

Kata kunci: Antioksidan, gula aren.

\section{ABSTRACT}

Palm sugar with a dose of $200 \mathrm{mg} / \mathrm{kg} \mathrm{BB}$ and $400 \mathrm{mg} / \mathrm{kg} \mathrm{BB}$ given to white rats which then induced $\mathrm{CCl}_{4} 1.5 \mathrm{ml} / \mathrm{kg}$ BB. This study aims to look at the levels of antioxidant enzymes namely SOD and GPx after $\mathrm{CCl}_{4}$ induction and the damage caused by $\mathrm{CCl}_{4}$ through MDA level measurements. The results showed that SOD and GPX levels in negative control rats differed from SOD and GPx levels in rats given palm sugar. The levels of antioxidant enzymes in rats given palm sugar were almost the same as those in normal rats ( $\mathrm{CCl}_{4}$-induced groups). This is related to MDA levels where in the negative control group rats showed high MDA levels while in normal rats and group rats given palm sugar showed low MDA levels which means that the antioxidant enzymes in normal rats and group rats given palm sugar made damping against oxidation reactions which is caused by $\mathrm{CCl} 4$ so that the lipid peroxidation that occurs is very small.

Kata kunci: Antioxidant, palm sugar.

\section{PENDAHULUAN}

Pembuatan gula aren yang diawali dengan proses pemanasan dalam waktu berjam-jam hingga terbentuk serbuk ataupun padatan gula aren selain untuk menghilangkan kadar airnya juga dalam proses tersebut terjadi reaksi Mailard yang membuat gula aren menjadi warna coklat. Pada tahapan akhir dari reaksi mailard menghasilkan produk akhir yang salah satunya adalah melanoidin. Melanoidin merupakan polimer yang berbasis karbohidrat dan nitrogen yang memiliki berat molekul besar serta terbentuk pada tahap akhir reaksi Mailard. Melanoidin terbentuk selama proses pemanasan karbohidrat yang berkontribusi pada beberapa sifat fisik maupun kimia suatu makanan seperti warna, aroma dan tekstur (Miotto, 2011).

\footnotetext{
Korespondensi:

Telepon: +62 852-4030-8901

Email: ellysuoth@gmail.com

DOI: https://doi.org/10.35799/cp.13.1.2020.28840
}

Berbagai penelitian dilakukan terhadap senyawa melanoidin ataupun produk dari reaksi mailard. Diantaranya adalah uji antioksidan dan hepatoprotektif dari susu yang dicampur dengan beberapa jenis gula dan dipanaskan pada suhu $55^{\circ} \mathrm{C}$ terbukti memiliki aktivitas antioksidan yang tinggi dan memberikan perlindungan terhadap organ hati. Beberapa penelitian lain yang menunjukkan bahwa produk dari reaksi mailard memiliki aktivitas sebagai antioksidan. Penelitian yang ada telah membuktikan bahwa gula aren memiliki aktivitas sebagai antioksidan dan stabil pada pemanasan dengan metode FRAP (Pelealu dkk., 2011) serta penelitian dari Muhamad dkk. (2010) yang melaporkan aktivitas antioksidan gula aren dengan metode DPPH selain itu Choong dkk (2016) melaporkan berdasarkan hasil penelitian perbandingan aktivitas antioksidan antara gula aren dengan gula putih dimana gula aren memiliki aktivitas antioksidan sebesar 28,88 
$\%$ sedangkan gula putih hanya memiliki aktivitas antioksidan sebesar $0,16 \%$.

Aktivitas antioksidan dari gula aren kemungkinan disebabkan oleh senyawa melanoidin yang terbentuk selama pemanasan pada proses pembuatan gula tersebut. Berdasarkan hasil laboratorium menunjukkan bahwa pada gula aren selain mengandung karbohidrat juga mengandung asam-asam amino protein yang dapat bereaksi membentuk reaksi Mailard pada proses pemanasan.

\section{METODE PENELITIAN}

\section{Bahan}

Bahan yang digunakan dalam penelitian ini adalah gula aren serbuk yang diperoleh dari pabrik gula aren Yayasan Masarang di Tomohon, Sulawesi Utara. Bahan untuk induksi yang digunakan adalah $\mathrm{CCl}_{4} \quad 1,5 \mathrm{ml} / \mathrm{kg}$ BB dengan konsentrasi $50 \%$ dalam larutan minyak kelapa serta bahan uji untuk pengukuran SOD, GPx dan MDA

\begin{abstract}
Alat
Alat yang digunakan dalam penelitian ini adalah timbangan, mikropipet, inkubator sentrifuge spektrofotometer, inkubator serta alatalat gelas lainnya yang lazim digunakan dalam laboratorium.
\end{abstract}

\section{Perlakuan terhadap hewan uji}

Tikus dipuasakan kemudian ditimbang. Kemudian pada hari itu juga diberikan gula aren sesuai dengan dosis $200 \mathrm{mg} / \mathrm{kg}$ BB dan $400 \mathrm{mg} / \mathrm{kg}$ BB selama 14 hari dan pada hari ke-15 diberikan larutan $\mathrm{CCl}_{4}$ sebanyak $1,5 \mathrm{ml} / \mathrm{kg} \mathrm{BB}$. Pada hari ke-16 tikus dikorbankan kemudian diambil organ hatinya, dibersihkan dan diproses untuk uji aktivitas enzim SOD dan GPx serta penetapan kadar MDA. Sampel hati dicacah dalam kondisi dingin kemudian ditambahkan $5 \mathrm{ml}$ larutan phosphate buffer saline (PBS) yang mengandung $11,5 \mathrm{~g} / \mathrm{L}$ KCL. Homogenat yang dihasikan kemudian di sentrifuge dengan kecepatan 4000 rpm selama 10 menit dan dilakukan sebanyak 2 kali hingga diperoleh supernatan yang jernih.

\section{Pengukuran aktivitas SOD.}

Aktivitas SOD dalam jaringan hati diukur dengan cara sebanyak $0,06 \mathrm{~mL}$ supernatan hati direaksikan dengan campuran yang terdiri dari 2,7 $\mathrm{mL}$ buffer natrium karbonat $50 \mathrm{mM}$ yang mengandung 0,1 mM EDTA (pH 10), 0,06 mL xantin $10 \mathrm{mM}, 0,03 \mathrm{~mL}$ bovine serum albumin (BSA) $0,05 \%$ dan $0,03 \mathrm{~mL}$ NBT $2,5 \mathrm{mM}$. Selanjutnya dilakukan penambahan xantin oksidase (0,04 unit). Inkubasi selama 30 menit kemudian absorbansinya dibaca pada spektrofotometer dengan panjang gelompang 560 nm. Sebagai kontrol digunakan larutan yang digunaakan dalam preparasi sampel hati yaitu PBS yang mengandung 11,5 g/L KCL. Aktivitas SOD (\%) dihitung dengan menggunakan persamaan : (1-(A/B) x 100\%)

Keterangan : $\mathrm{A}=$ absorbansi larutan sampel; $\mathrm{B}=$ absorbansi larutan kontrol

\section{Pengukuran aktivitas GPx.}

Sebanyak $20 \quad \mu l$ supernatan hati ditambahkan $200 \mu \mathrm{l}$ buffer fosfat $0,1 \mathrm{M} \mathrm{pH} 7$ yang mengandung $0,1 \mathrm{mM}$ EDTA, $200 \mu$ l glutation tereduksi (GSH) $10 \mathrm{mM}$ dan $200 \mu 1$ enzim glutation reduktase (2,4 unit). Inkubasi selama 10 menit pada suhu $37^{\circ} \mathrm{C}$ kemudian ditambahkan 200 $\mu 1 \mathrm{NADPH}$ 1,5 $\mathrm{mM}$ dan diinkubasi lagi selama 3 menit pada suhu yang sama dan dilanjutkan dengan penambahan $200 \mu 1 \mathrm{H}_{2} \mathrm{O}_{2}$ 1,5 mM. Laju perubahan serapan selama konversi NADPH menjadi $\mathrm{NADP}^{+}$direkam secara spektrofotometri pada panjang gelombang $340 \mathrm{~nm}$ selama 3 menit. Aktivitas GSH-Px dinyatakan sebagai $\mu \mathrm{mol}$ $\mathrm{NADPH}$ yang dioksidasi menjadi NADP ${ }^{+}$menit $^{-1}$ $\mathrm{mg}^{-1}$ protein dengan koefisien ekstrinsik $6,22 \mathrm{mM}^{-}$ ${ }^{1} \mathrm{~cm}^{-1}$ untuk NADPH dengan perhitungannya sebagai berikut :

$M$ unit GSH-Px $=\frac{\text { Abs x Vt x } 2 \times 1000 \times \frac{1}{\mathrm{mg}} \text { protein }}{6,22 \times \mathrm{Vs}}$

Abs $=$ perubahan absorbansi; $\mathrm{Vt}=$ Volume total (ml); 6,22 = Koefisien ekstrinsik dari NADPH; 2 $=2 \mathrm{~mol} \mathrm{GSH}$ yang setara dengan $1 \mathrm{~mol} \mathrm{NADPH}$; $1000=$ Perubahan menjadi mili unit; Vs $=$ Volume sampel

\section{Pengukuran kadar MDA.}

Sebanyak $0,5 \mathrm{ml}$ supernatan hati ditambahn $2 \mathrm{ml}$ campuran larutan dingin ( $\mathrm{HCl}$ dingin $0,25 \mathrm{~N}$ (2,23 $\mathrm{ml} \mathrm{HCl} \mathrm{pekat/100} \mathrm{ml})$ yang mengandung 15 $\%$ TCA $0,38 \%$ TBA $0,5 \%$ BHT). Campuran dipanaskan pada suhu $80^{\circ} \mathrm{C}$ selama 1 jam. Setelah dingin campuran disentrifuge dengan kecepatan $3500 \mathrm{rpm}$ selama 10 menit. Absorbansi supernatan dibaca pada spektrofotometer dengan panjang gelombang $532 \mathrm{~nm}$. Larutan standar yang digunakan adalah tetraetoksipropana (TEP). 


\section{HASIL DAN PEMBAHASAN}

\section{Pemastian standar mutu gula aren}

Gula aren yang diambil dari pabrik gula aren Masarang kemudian diidentifikasi secara organoleptik dan dianalisis kandungan kimianya sesuai dengan Standar Nasional Indonesia (SNI).
Identifikasi dilakukan untuk memastikan bahwa gula aren serbuk yang digunakan sesuai dengan syarat mutu yang telah ditetapkan oleh SNI. Hasil identifikasi dan analisis dapat dipastikan bahwa gula aren serbuk yang digunakan sebagai sampel dalam penelitian ini memenuhi syarat mutu berdasarkan SNI.

Tabel 1. Hasil organoleptik dan analisis gula aren

\begin{tabular}{cllll}
\hline No & Kriteria Uji & \multicolumn{1}{c}{ Hasil Uji } & Persyaratan & \multicolumn{1}{c}{ Keterangan } \\
\hline 1 & Bentuk & Serbuk & Serbuk & Sesuai persyaratan \\
2 & Rasa & Normal & Normal & Sesuai persyaratan \\
3 & Aroma & Aroma khas & Khas & Sesuai persyaratan \\
4 & Warna & Kuning Kecoklatan & Kuning & Sesuai persyaratan \\
& & & kecoklatan & \\
& & & sampai coklat & \\
\hline
\end{tabular}

Berdasarkan tabel 1 diatas dapat dilihat bahwa hasil organoleptik terhadap gula aren yang diperoleh baik berdasarkan bentuk, rasa, aroma

dan warna semuanya sesuai dengan persyaratan yang ditetapkan oleh Standar Nasional Indonesia.

Tabel 2. Karakteristik fisikokimia gula aren

\begin{tabular}{lllll}
\hline 1 & Bagian yang tak larut air & 0,17 & Maks 1 & Sesuai persyaratan \\
\hline 2 & Air & 1,65 & Maks 10 & Sesuai persyaratan \\
3. & Abu & 2,17 & Maksl 2 & Sesuai persyaratan \\
4. & Gula pereduksi & 1,93 & Maks 10 & Sesuai persyaratan \\
5. & Jumlah gula sebagai sakarosa & 83,85 & Min 90 & Sesuai persyaratan \\
6 & Zeng $(\mathrm{Zn})$ & $<0,0021$ & Maks 40 & Sesuai persyaratan \\
7 & Timbal $(\mathrm{Pb})$ & 0,41 & Maks 2 & Sesuai persyaratan \\
8 & Tembaga $(\mathrm{Cu})$ & 1,31 & Maks 10 & Sesuai persyaratan \\
9 & Raksa $(\mathrm{Hg})$ & $<0,0008$ & Maks 0,03 & Sesuai persyaratan \\
10 & Timah $(\mathrm{Sn})$ & 11,26 & Maks 40 & Sesuai persyaratan \\
11 & Arsen & $<0,001$ & Maks 1 & Sesuai persyaratan \\
12 & Formalin & - & & \\
\hline
\end{tabular}

Tabel 2 dapat dilihat bahwa semua komponen persyaratan karakteristik fisikokimia gula aren yang dianalisis mengikuti persyaratan SNI baik itu yang berupa kandungan gula serta kandungan logam yang ada pada gula aren serbuk yang dijadikan sampel, hasil analisisnya menunjukkan bahwa semuanya memenuhi persyaratan seperti yang telah ditetapkan.

\section{Hasil pengukuran aktivitas enzim SOD, GPx dan MDA}

Sifat antioksidan dari gula aren serbuk diamati pada jaringan hati tikus melalui analisis SOD dan GPx yang hasil analisisnya dapat dilihat pada tabel
Tabel 3. Hasil pengukuran kadar SOP dan GPx tikus

\begin{tabular}{ccl}
\hline Kelompok & $\begin{array}{c}\text { Kadar SOD } \\
(\%)\end{array}$ & $\begin{array}{c}\text { Kadar GPx } \\
(\mathrm{U} / \mathrm{mg})\end{array}$ \\
\hline I & $79,65 \pm 6,7$ & $85,66 \pm 1,7$ \\
II & $23,51 \pm 4,7^{\mathrm{a}}$ & $37,35 \pm 3,2^{\mathrm{a}}$ \\
III & $64,91 \pm 4,4^{\mathrm{ab}}$ & $76,09 \pm 2,35^{\mathrm{ab}}$ \\
IV & $41,75 \pm 5,8^{\mathrm{abc}}$ & $58,80 \pm 2,7^{\text {abc }}$ \\
V & $58,25 \pm 5,0^{\text {abcd }}$ & $70,38 \pm 1,4^{\text {abcd }}$ \\
\hline
\end{tabular}

a menunjukkan $\mathrm{P}<0,05$ dibandingkan dengan kontrol normal; $\mathrm{b}$ menunjukkan $\mathrm{P}<0,05$ dibandingkan dengan kontrol negatif; $c$ menunjukkan $\mathrm{P}<0,05$ dibandingkan dengan kontrol positif; $\mathrm{d}$ menunjukkan $\mathrm{P}<0,05$ dibandingkan dengan dosis gula aren $200 \mathrm{mg} / \mathrm{kg}$ BB

Keterangan :

$$
\begin{array}{ll}
\text { I } & =\text { Kelompok normal } \\
\text { II } & =\text { Kelompok kontrol negatif }
\end{array}
$$




$$
\begin{array}{ll}
\text { III } & =\text { Kelompok kontrol positif (Hepamax) } \\
\text { IV } & =\text { Gula aren dosis } 200 \mathrm{mg} / \mathrm{kg} \mathrm{BB} \\
\mathrm{V} & =\text { Gula aren dosis } 400 \mathrm{mg} / \mathrm{kg} \mathrm{BB}
\end{array}
$$

Kadar SOD dan GPx pada jaringan hati tikus berdasarkan tabel di atas dapat dilihat bahwa dibandingkan dengan kelompok kontrol normal, kelompok II sampai kelompok $\mathrm{V}$ mengalami penurunan. Penurunan kadar SOD dan GPx terjadi karena kedua enzim tersebut melakukan perlindungan terhadap sel pada organ hati dari kerusakan yang ditimbulkan oleh radikal bebas setelah induksi $\mathrm{CCl}_{4}$. Penurunan yang sangat besar terjadi ada kontrol negatif. Namun berdasarkan hasil uji statistik terdapat perbedaan pada tiap kelompok baik itu pada kadar SOD maupun pada kadar GPx. Hal ini menunjukkan bahwa pemberian gula aren dapat mempengaruhi kadar SOD serta GPx dalam jaringan hati tikus. Penurunan kadar SOD dan GPx pada kelompok dosis gula aren dosis $200 \mathrm{dan} 400 \mathrm{mg} / \mathrm{kg}$ BB yang besarnya tidak sama dengan kontrol negatif menunjukkan bahwa gula aren dapat bertindak sebagai antioksidan dan bekerja bersama-sama dengan enzim SOD dan GPx dalam meredam reaksi oksidasi yang disebabkan oleh radikal bebas dalam jaringan hati tikus.

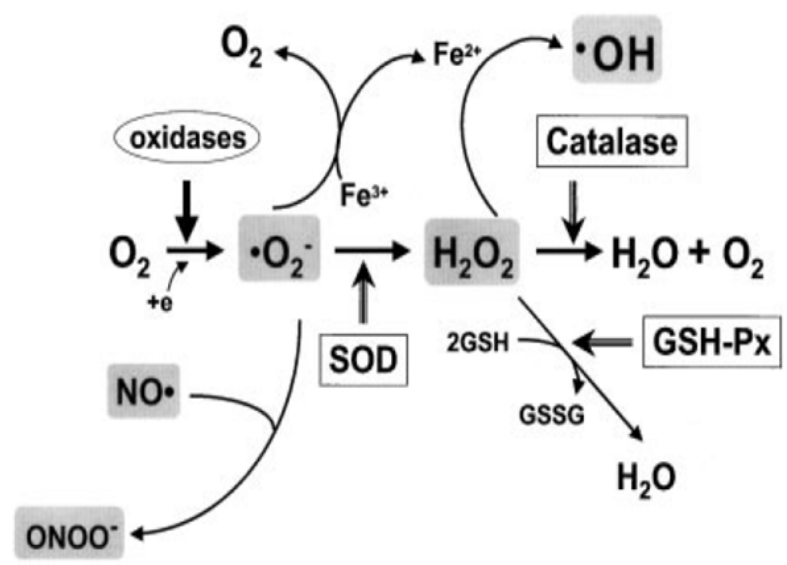

Gambar 1. Reaksi peredaman radikal bebas oleh antioksidan eksogen(Koek dkk., 2011)

Sistem antioksidan dalam sel mamalia seperti SOD dan GPx berfungsi untuk menghambat radikal bebas sehingga terjadi perlindungan pada organ hati yang diinduksi oleh $\mathrm{CCl}_{4}$. SOD merupakan metaloenzim yang terdapat dalam sub seluler dan mengandung tembaga atau seng dan mangan yang berfungsi sebagai antioksidan dalam mengkatalis anion superoksida dismutase menjadi hidrogen peroksida dan oksigen, sedangkan GPx mengkatalis hidrogen peroksida menjadi senyawa yang tidak toksik.
Tabel 3. Hasil pengukuran MDA tikus

\begin{tabular}{cc}
\hline Kelompok & Kadar MDA (nmol/gr) \\
\hline I & $1,22 \pm 0,1$ \\
II & $7,62 \pm 0,2^{\mathrm{a}}$ \\
III & $1,66 \pm 0,1^{\mathrm{ab}}$ \\
IV & $3,42 \pm 0,5^{\mathrm{abc}}$ \\
V & $1,96 \pm 0,1^{\mathrm{abcd}}$
\end{tabular}

a menunjukkan $\mathrm{P}<0,05$ dibandingkan dengan kontrol normal; $\mathrm{b}$ menunjukkan $\mathrm{P}<0,05$ dibandingkan dengan kontrol negatif; $\quad \mathrm{c}$

menunjukkan $\mathrm{P}<0,05$ dibandingkan dengan kontrol positif; $\mathrm{d}$ menunjukkan $\mathrm{P}<0,05$ dibandingkan dengan dosis gula aren $200 \mathrm{mg} / \mathrm{kg}$ BB.

Keterangan :

$$
\begin{array}{ll}
\text { I } & =\text { Kelompok normal } \\
\text { II } & =\text { Kelompok kontrol negatif } \\
\text { III } & =\text { Kelompok kontrol positif (Hepamax) } \\
\text { IV } & =\text { Gula aren dosis } 200 \mathrm{mg} / \mathrm{kg} \mathrm{BB} \\
\text { V } & =\text { Gula aren dosis } 400 \mathrm{mg} / \mathrm{kg} \mathrm{BB}
\end{array}
$$

Jika pada enzim SOD dan GPx terjadi penurunan kadar pada kelompok II-V menandakan bahwa enzim-enzim tersebut mengadakan peredaman terhadap reaksi oksidasi yang disebabkan oleh induksi $\mathrm{CCl}_{4}$ maka lain hal nya yang terjadi pada kadar MDA. Pada kelompok normal kadar MDA yang diperoleh sangat kecil yang menunjukkan bahwa peroksidasi lipid yang terjadi sangatlah kecil sehingga menghasilkan produk akhir yang berupa MDA sangat kecil juga. Namun dapat dilihat pada kelompok II-V menunjukkan peningkatan kadar MDA yang berarti bahwa peroksidasi lipid yang terjadi semakin besar dengan adanya induksi $\mathrm{CCl}_{4}$. Peningkatan kadar MDA yang terbesar terjadi pada kontrol negatif, sedangkan pada kontrol positif dan kelompok gula aren dosis 400 $\mathrm{mg} / \mathrm{kg}$ BB terjadi peningkatan yang kecil jika dibandingkan dengan kontrol normal.

\section{KESIMPULAN}

Berdasarkan penelitian yang dilakukan disimpulkan bahwa gula aren serbuk memiliki aktivitas antioksidan yang ditunjukkan dengan tetap tingginya kadar enzim SOD dan GPX pada kelompok hewan dengan dosis gula aren 200 $\mathrm{mg} / \mathrm{kg}$ BB serta kelompok dosis $400 \mathrm{mg} / \mathrm{kg}$ BB yang diinduksi dengan $\mathrm{CCl}_{4}$, serta angka MDA yang rendah menunjukan peroksidasi lipid yang terjadi juga kecil pada kedua kelompok hewan uji dengan kedua dosis tersebut 


\section{DAFTAR PUSTAKA}

Alam, N.M., Bristi, N.J. \& Rafiquzzaman, M. 2013. Review on in vivo and in vitro methods evaluation of antioxidant activity. Saudi Pharmaceutical Journal. 21(2), 149152.

Cammerer, B., Jalyschkov, V. \& Kroh, L.W. 2002. Carbohydrate structures as part of the melanoidin skeleton. International Congress Series. 1245, 269-273.

Cammerer, B., Jalyschkov, W. \& Kroh, L.W. 2002. Intact carbohydrate structures as part of the melanoidin skeleton. Journal of Agricultural and Food Chemistry. 50(7), 2083-2087.

Chandra, R., Bharagava, R.M., Rai, V. 2008. Melanoidins as major colourant in sugarcane molasses based distillery effluent and its degradation. Bioresource Technology. 99(11), 4648-4660.

Chaudiere, J. \& Ferrari-Iliou, R. 1999. Intracellular antioxidants: from chemical to biochemical mechanisms. Food and Chemical Toxicology. 37(9-10), 949-962
Choong, C.C., Anzian, A., Sapawi, C.W. \& Hussin M. 2016. Characterization of sugar from Arenga pinnata and Saccharum officinarum sugar. International Food Research. 23(4), 1642-1652

Esposito, F., Morisco, F., Verde, V., Ritieni, A., Alezio, A., Caporaso, N. \& Fogliano, V. 2003. Moderate coffee consumption increases plasma glutathione but not homocysteine in healthy subjects. Alimentary Pharmacology Therapeutics. 17(4), 595-601.

Hayase, F., Hirashima, S., Okamoto, G. \& Katom H. 2014. Scavenging of Active Oxygens by Melanoidins. Agricultural and Biological Chemistry. 53(12), 3383-3385.

Jialong, F., Wu, Z., Zhao, T., Sun, Y., 2014. Characterization, antioxidant and hepatoprotective activities of polysaccharides from Ilex latifolia Thunb. Carbohydrate Polymers. 101, 990-997.

Brudzynski, K. \& Miotto. D. 2011. Honey melanoidins: analysis of the compositions of the high molecular weight melanoidins exhibiting radical-scavenging activity. Food Chemistry. 127(3), 1023-1030. 